\title{
MONGOLIA: ECONOMIC SLUMP, DEMOCRATIC BACKSLIDING AND PRESSURE FROM THE NEIGHBOURS
}

by Axel Berkofsky

\section{Introduction}

The landlocked Mongolia's near-complete economic dependence on China and Russia is here to stay and the global pandemic has made it painfully clear that when China sneezes Mongolia catches a serious cold. The government and the state reacted and adopted a massive economic and fiscal stimulus package to - at least in parts and at least for now - counter the pandemic's repercussions for the country's economy. 2020 was not a good year for Mongolian democracy. As will be shown below, the June 2020 elections put the country onto the path of what is also referred to as democratic backsliding. A path from an accountable (relatively) liberal democracy towards what in the case of Mongolia is becoming a quasi one-party democracy burdened by corruption and nepotism - resulting in the violation of principle of separation of powers. To be sure, Mongolia's political rulers do not necessarily need incentives from the outside to replace democratic with authoritarian governance in Mongolia and the country's democratic backsliding is surely observed with satisfaction in both Moscow and Beijing. While China does not question Mongolian independence, there are concerns that the stronger and economically powerful China becomes, the more it might get tempted to make also Outer Mongolia, i.e. today's Mongolia, part of Chinese territory in the not-so-distant future. Beijing's decision in mid-2020 to further eradicate the Mongolian language, culture and cultural heritage in the Inner Mongolia Autonomous Region

Dipartimento di Scienze Politiche e Sociali, Università di Pavia. 
in China set off a number of alarm-bells in Mongolia's capital Ulaanbaatar. Mongolian President Battulga Khaltmaa in the meantime, at least so it seems, is eager to get into Russia and China's good books and considers giving in to Moscow's urging to replace Mongolia's observer status with full membership in the Shanghai Cooperation Organization (SCO).

Before the outbreak of the global pandemic Mongolia had a US\$ 13.5 billion economy ${ }^{1}$. As will be shown below, the country's economy has taken a massive hit in 2020. Indeed, the global pandemic could not have exposed Mongolia's economic vulnerabilities more clearly: extreme or indeed excessive dependence on China as its main export market, typically accounting for close to 95\% of the country's total coal, copper and gold above all. When the global pandemic hit the global economy, Mongolia's exports declined by around $42 \%$ year-on-year in the first three months of 2020. Coal exports contracted by $62 \%$ as a result of weaker demand and partial border closure for freight cargo ${ }^{2}$. On a positive note, until November 2020 Mongolia was a Covid-19 success story. The government reacted quickly to the outbreak of Covid19 in January 2020 and Mongolia's relative isolation made it possible for the government to close the country's borders quickly. The country only experienced its first community infections in November 2020, leading at the time to a very strict lockdown 3 .

In an attempt to counter near-complete economic disaster, the Mongolian government adopted economic stimulus measures in 2020, which included personal income tax and social insurance contribution exemptions for employees and employers, a corporate income tax waiver and a significant increase of the so-called Child Money Trans-

1 Country Report Mongolia July 1st, 2019, "Economist Intelligence Unit", London, UK. With 2 people living per square kilometre, Mongolia is one of the least densely populated countries in the world. Mongolia's population is roughly 3.3 million and Mongolia's total land area amounts to 1.55 million square kilometres. More than five times France's and more than nine times Germany's total land area.

2 For more details see e.g. Regional Economic Prospects. Covid-19: from Shock to Recovery, in "European Bank for Reconstruction and Development", May 20, 2020.

3 C. Krusekopf M. Jargaksaukhan, Mongolia's Bittersweet Covid-19 Success, in "East Asia Forum", August 27, 2020; also see J. Dierkes, Mongolia Weathers the Storm of 2020, in "EastAsiaForum", January 14, 2021 and A. BAYARJAGali, Mongolia's Success and Challenges against Covid-19, in "East Asia Forum", August 13, 2020. 
fer. This is a welfare program for families with children who live below the poverty line. Furthermore, The Bank of Mongolia (вом) and the country's Financial Regulatory Commission implemented a number of temporary financial leniency measures to guarantee the stability of the country's banking and financial systems. Currently, the expanded (albeit temporary) social safety net provides some relief for the most economically vulnerable, although a significant part of the population could be confronted with an elevated risk of falling into poverty in 2021 and beyond. More than 30 percent of Mongolia's citizens today live below the poverty line 4 . Overall, the economic stimulus package amounted to roughly (US $\$ 1.8$ billion), a lot of money for a US $\$ 13.5$ billion economy. Throughout 2020, Mongolia has received both loans and grants from the World Bank and the Asian Development Bank (ADB) and the $\mathrm{ADB}$ in particular is actively supporting numerous development projects in the country5.

In June 2020 Mongolia voted a new parliament, which confirmed the Mongolian People's Party's (MPP) dominance in Mongolian politics, setting the country onto the path of a one-party democracy. A new election law adopted in December 2019 has favoured continuous MPP dominance in Mongolian politics, assigning (even) greater weight and importance to votes in the country's rural districts. Furthermore, as will be explained below, the elections of June 2020 and the arrest of five parliamentary candidates in violation of the principle of separation of powers and in violation of the constitutionally guaranteed immunity of politicians running for office - are indications of the persistent fragility of Mongolian democracy ${ }^{6}$. A democracy that has often prided itself with being a democratic oasis in a non-democratic and authoritarian neighbourhood.

4 See Economic Concerns High as Mongolia Holds National Elections, in "Associated Press", June 24, 2020.

5 In 2020, the ADB sponsored projects in the areas of sustainable/renewable energy development, institutional capacity-building, medicine safety and disease control. For a very detailed account of the ADB's operations and projects see Mongolia 2021, ADB Country Operations Business Plan, in “Asian Development Bank (ADB)” August 2020.

6 See Has Court Breached Former Prime Minister's Parliamentary Immunity?, ,in "Montsame, Mongolian News Agency", June 18, 2020. 


\section{Recession, Debt, Economic Stimulus}

In the first half of 2020, Mongolia GDP shrank by almost $10 \%$ while exports and imports from January to August 2020 decreased by 17 and $15.5 \%$ respectively as compared with the same period in $2019^{7}$. The World Bank in October 2020 cites a survey by the Mongolian Chamber of Commerce (MCC), which reports that roughly 8.000 jobs in Mongolia have been lost since the Covid-19 outbreak in early 2020. That number, the World Bank writes in October 2020, has further increased throughout the year 20218. In February 2020 Mongolia's coal exports to China were all but completely interrupted and only resumed in mid-March. By the end of the year 2020 Mongolia's overall coal exports have decreased by more than $20 \% .95 \%$ of Mongolia's coal is exported to China. On the (potentially) bright side, FocusEconomics projects that Mongolia's economy will grow by $6.7 \%$ in 2021 and $6.1 \%$ in $2022^{9}$.

Gan-Ochir Doojav from the Bank of Mongolia (вом) explains that the country's Ministry of Finance introduced fiscal stimulus equivalent to $7.2 \%$ of GDP. This included the (temporary) reduction of social security contributions, health spending and increases in Mongolia's aforementioned Child Money Transfer. Obviously all of this was not without fiscal consequences. The country's budget passed at the very end 2020 shows that Mongolia's overall fiscal balance amounted to minus $12.5 \%$ in 2020. Depending on the level of economic - and therefore also fiscal - recovery, the fiscal balance will improve and reach minus $5.1 \%$ by the end of $2021^{10}$. The вом has throughout the year 2020 adopted additional measures to counterbalance the pandemic's economic and fiscal repercussions. Among others, BOM reduced policy interest rate by 500 basis points (i.e. $0.5 \%$ ), reduced the reserve requirement by 4.5 percentage points and temporarily suspended the debt-service-to-in-

7 Mongolia: Updated Assessment of the Impact of the Corona Pandemic on the Extractive Sector and Resource Governance, in "National Resource Governance Institute Briefing", October 28, 2020.

8 The World Bank in Mongolia,October 6, 2020.

9 Mongolia Economic Outlook, in "FocusEconomics", November 17, 2020.

10 G. Doojav, Mongolia's Economic Outlook, in "East Asia Forum”, December 31, 2020. 
come ceiling on consumer loans. Furthermore, the bank provided targeted longer-term financing to the banking sector as authorized by Mongolia's Covid-19 emergency legislation ${ }^{11}$. As regards the country's financial sectors, the вом has extended maturities on consumer and mortgage loans and has authorized banks to restructure loans to business loans - this in order to reduce the pressure on borrowers.

And then there is Mongolia's debt. Mongolia's public (government) debt amounts to $70 \%$ of the country GDP (out of which more than $90 \%$ is denominated in foreign currency). Mongolia's overall external debt (public, private and corporate debt combined) amounts to a staggering $220 \%$ of GDP ${ }^{12}$. Mongolia's public debt has further increased in 2021, not least due to aforementioned economic and fiscal stimulus package ${ }^{13}$. The country's current account deficit amounts to roughly $15 \%$ of GDP each year and gross reserves are equivalent to only 8 months of imported goods (roughly us $\$ 3.6$ billion). Consequently, any new reduction in exports would put additional pressure on the country's balance of payments and quickly eat up Mongolia's foreign currency reserves, helping to keep Mongolia's currency afloat. Furthermore, Mongolia is burdened by a high level of non-performing loans, amounting to close to $12 \%$ in December 202014. The level of non-performing loans in Japan in 1989/1990 was lower than that (between 8 and 9\%) when the country's banking and financial sectors collapsed. Finally, to make financial matters even more complicated, since 2020, Mongolia entered a period of re-payment of its bonds. In the past Mongolia has adopted a currency swap agreement with China (an agreement between the central banks of both countries). This agreement was scheduled to end in 2020 , i.e. Mongolia would have been obliged to re-pay loans taken from China by the end of 2020. In August 2020, however, the BOM announced that the re-payment has been re-scheduled and ex-

${ }^{11}$ See e.g. Rule of Law in the Time of Covid-19: Mongolia, in "International Development Law Organization (IDLO)", July 20, 2020. See also Covid-19 Prevention Law Passed, in "Montsame, Mongolian News Agency", April 30, 2020.

${ }^{12}$ Mongolia's Total External Debt 2009-2020 Data, in "Trading Economics", December 2020 .

13 World Bank Group's Response to Covid-19 in Mongolia, in "World Bank", October 12, 2020.

${ }^{14}$ For further data see also Mongolia Non Performing Loans Ratio, in "Census and Economic Information Center (CEIC)", December 2020. 
tended until 2023. More time to re-pay a us $\$ 2.2$. billion granted by China's central bank. Urgently needed additional time.

\section{Mining and Coal}

Mongolia's mining industry typically takes up a share of $21 \%$ of the GDP, 70-75\% of foreign direct investment, and between and 80 and $90 \%$ of export earnings. Obviously, the dramatic decrease of mining exports in 2020 weighed heavily on the government's budget. Consequently, the country's tax revenue fell by around 20 per cent and social security contributions were down by 40 per cent in the first half of the year. On February 10, 2020, China de facto closed its borders and most Mongolian mineral exports were interrupted at the time ${ }^{15}$. Coal exports to China started to (gradually) resume on March 15 and were back to pre-pandemic levels by August 2020. Coal exports to China have further increased in the second half of 2020, but in December 2020 were still almost $50 \%$ lower than in the same month a year ago. China in 2020 bought $95 \%$ of Mongolia's coal and did the same in 2021: there really is nowhere else to go for Mongolia's coal but to China. And the electricity for Mongolian mines too still comes from China. In recent years, the Mongolian government - together with the Anglo-Australian mining group Rio Tinto ${ }^{16}$ - have undertaken efforts to a build power plant in Mongolia, in order to reduce or indeed eliminate electricity dependence on China. Albeit with a lot of problems and delays with little prospects of actually being able to build a power plant as a substitute for electricity provided by China any time soon.

The Oyu Tolgoi (От) Mining Project, located in the southern part of the Gobi desert, will become the world's fourth-largest copper mine, producing 480.000 tonnes of copper per year. The project is set to become fully operational by 2023 . However, issues related to ownership of the mine remain unresolved and back in 2019 the Mongolian parliament asked for the renegotiation of the От mining project contract terms to

\footnotetext{
15 'Mongolia Suspends Coal Exports to China on Coronavirus Fears', in "Reuters", February 10, 2020.

16 The world's second largest metals and mining corporation.
} 
seek an increase of the state's ownership stake. Oт is jointly owned by Mongolia's state (34\%) and Turquoise Hill Resources (66\%, of which Rio Tinto owns $51 \%$ ). If and once fully operational, the mine's contribution to Mongolia's economy could indeed be enormous. It is expected to contribute up to $30 \%$ of Mongolia's GDP by 202717 . Oyu Tolgoi, however, was already facing delays and cost overruns before the global pandemic due to technical issues and disputes with the Mongolian government (which holds a 34\% share). Delays Mongolia's government wants a second opinion on as it turned out in November 2020. The government has requested an independent inquiry into the delays and steadily rising costs of the mine's underground expansion (from US $\$ 5.3$ to close to US $\$ 7.1$ billion over recent years). At the time the government announced to want to establish a special committee of board of directors to identify and employ an independent company to investigate the delays and rising $\operatorname{costs}^{18}$. In December 2020 then Rio Tinto announced - apparently without checking with the Mongolian government - to start copper production by October 2022 if and when pending approvals come in, the above-mentioned power plant was built and when it reached an agreement with the government on financing ${ }^{19}$. That, however, was Rio Tinto reckoning without its host, which at the time declared that it was not aware of any pending government approvals. This led the government at the very end of 2020 to threaten to end the current agreement with Rio Tinto and request a new one with improved terms Mongolia. The government has for some time been concerned about never actually receiving a dividend from the project in light of the debt it has taken to develop the mine and finance the underground expansion. Rio Tinto management was in January 2021 cited by The Financial Times as saying to be "open to improving the terms of the agreement" 20 .

Against the background of the US $\$ 11$ billion the company has invested in the project since 2010 , that certainly is not a surprise.

${ }^{17}$ Mongolia has approximately $10 \%$ of world's known coal reserves.

${ }^{18}$ N. Hume, Mongolia Raises Heat on Rio Tinto over Vast Oyu Tolgoi Copper Mine, in "The Financial Times", November 25, 2020.

19 N. Hume, Rio Eyes Production from Mongolia Copper Project in 2022, in "The Financial Times", December 16, 2020.

${ }^{20}$ N. Hume, Mongolia Threatens to Halt Rio Tinto Copper Project, in "The Financial Times", January 11, 2021. 


\section{Elections - On a Path to Autocracy}

Since it became a democracy in 1991, Mongolia has what is referred to as "hybrid" political system, in which power is shared by an elected president and the government, which in turn is nominated by the 76-member unicameral parliament and headed by a Prime Minister $^{21}$. In June 2020, Mongolia's ruling party, The Mongolian People's Party (MPP) won a landslide victory at the general elections. The MPP won $62^{22}$ out of the 76 seats in the parliament, again securing the parliamentarian supermajority the party won in 201623. Prime Minister Khurelsukh Ukhnaa has another four years to govern in Mongolia. The parliament's main opposition party - the Democratic Party (DP) - was able to win 11 seats while the remaining three seats were divided between the former Prime Minister N. Altankhuyag (who ran as an independent), the Mongolian People's Revolutionary Party, and the National Labour Party. The turnout was close to $73 \%{ }^{24}$. The elections were a de facto confirmation of one-party dominance in Mongolia, and also another step towards a de facto one-party democracy country (accompanied by the aforementioned democratic backsliding). A country that is, as the example of Japan has impressively demonstrated over decades, prone to massive corruption and clientelism, i.e. the ruling party receiving financial aid and perks in return for favourable policies for the party's clients (industry, agricultural sector etc.) ${ }^{25}$. And there is already a very fertile ground for corruption in Mongolia. Take e.g. the November 2018 corruption scandal related to a state funded financing scheme for private businesses, the so-called SME Fund, which shook Mongolian politics. The fund provided low-interest loans to small and

${ }^{21}$ For further details explaining the hybrid nature of Mongolia's political and governance systems see e.g. J. DIERKES, Preserving the Political Status Quo in Mongolia, in "East Asia Forum", January 10, 2020.

22 Although it lost 3 seats in 2020. It held 65 after the 2016 general elections.

${ }^{23}$ B. BATDORJ, Mongolia and the Survival in an Authoritarian Neighbourhood, in "ISPI Commentary"; Istituto per gli Studi di Politica Internazionale (ISPI), June 29, 2020.

${ }^{24}$ Mongolia Elections: Landslide Win for the Incumbent MPP, in "Deutsche Welle", June 25, 2020.

25 In Japan, the Liberal-Democratic Party (LDP) governed without interruption from 1955 to 1993, thanks - like in Mongolia - to an electoral system that strongly favours the rural over the urban vote. 
medium-sized private companies and in order to receive the funds, a number of companies bribed government officials (amounting to a total US\$1.3 million of slush money) ${ }^{26}$.

An election law adopted December 2019 has further helped the MPP to expand its nationwide dominance in general and the one in rural electoral districts in particular. A change that transforms Mongolia election rules from a mixed system that uses both proportional and majoritarian voting to a winner takes all system. That is an electoral system that makes it more difficult for independent and third-party candidates to win seats (which is what de facto happened as only one independent candidate was voted into parliament in June 2020). Roughly 1 million of the 2.3 million Mongolian eligible voters voted in the capital Ulaanbaatar while only 24 parliamentary seats are allocated to the capital. The multi-member system requires candidates to be voted by bigger number of voters as compared to smaller singlemember districts. This favours big established parties with well developed institutional and supporter networks ${ }^{27}$. And that is especially relevant in 20 rural election districts from where 54 of 76 candidates are voted into parliament. In June 2020, a total of 606 candidates, representing 13 political parties and 4 coalitions were running for parliament $^{28}$. Out of that total, 121 independent candidates presented themselves, according to Julian Dierkes and Byambajav Dalaibuyan a result of a failing Mongolian party system the electorate has today little faith in ${ }^{29}$. And that is not at all a surprise as the established parties have turned to buying votes from the electorate in commodities rather than win elections by getting voters to support policies. The reason

${ }^{26}$ K. B AYARTSOGT, A Scandal in Mongolia: Heads Roll in Government After US\$1.3m SME Fund Embezzlement, in "South China Morning Post", November 5, 2018.

${ }^{27}$ For further details see M. J. SмIтH, Power of the People's Parties and a Post-Soviet Parliament: Regional, Infrastructural, Economic and Ethnic Networks of Power in Contemporary Mongolia in "Journal of Eurasian Studies", n. 2, July 2020, pp. 107-116. See also P. MASKARINEC, The 2016 Electoral Reform in Mongolia: from Mixed System and Multiparty Competition to FPTP and One-Party Dominance, in "Journal of African and Asian Studies", n. 4, 2018, pp. 511-531.

${ }^{28}$ See 606 Candidates Confirmed to Run for 2020 Parliamentary Election, in "Montsame Mongolian News Agency", June 2, 2020.

${ }^{29}$ See J. Dierkes and B. Dalaibuyan, Can Mongolia's Elections Shun Democratic Backsliding?, in "EastAsiaForum”, June 22, 2020. 
why the platforms and policy programmes of the country's two main political parties are in essence identical ${ }^{30}$.

\section{Democratic Backsliding}

Recent developments in Mongolian politics are consistent with what the literature refers to as democratic backsliding taking place in a number of democracies around the globe ${ }^{31}$. In Europe, Hungary and Poland can be cited as examples of countries which by now and after years of so-called 'illiberal democratic governance' can be referred to as semi-democracies. While the elections were free and fair, five candidates for parliament were arrested during the election campaign and charged ${ }^{32}$ for the alleged misuse of power and corruption in relation to Mongolia's the country's big mining projects. The scholar Bulgan Batdorj notes that the arrests were a violation of the country's Law on Elections, which is granting candidates parliament immunity from prosecution. She further adds that the charges were seen as politically motivated as the five arrested politicians have a track record of being critical of the country's Prime Minister and president. Arresting candidates during an election campaign, Julian Dierkes and Byambajav Dalaibuyan write, has never happened in Mongolia before and, as they point out, set a dangerous precedent for the quality of Mongolia's (fragile) democracy ${ }^{33}$. The arrests, Dierkes and Dalaibuyan conclude, were facilitated by a law adopted in March 2019, which de facto authorized the country's president, the Prime Minister and the speaker of parlia-

${ }^{30}$ See also P. BITTNER, Mongolia's Crisis of Democracy, in "The Diplomat", January $31,2019$.

${ }^{31}$ N. BERMEO, On Democratic Backsliding, in "Journal of Democracy", n.1, January 2016, Johns Hopkins University Press, pp. 5-19.

32 And later sentenced.

33 In March 2019, Mongolia's parliament adopted a law which authorized the country's National Security Council to sack judges, prosecutors and probably most importantly the head of the country's Anti-Corruption Agency. The law allows judges to be recused from any case, approved by the National Security Council and the Judicial General Council. Because the Judicial General Council is appointed by the president, the law is clearly a violation of the principle of separation of powers. Battulga fired the chief justice of the country's supreme court, the general prosecutor and his deputy right after the law's adoption. 
ment to fire judges and prosecutors as they seem fit. Furthermore, constitutional amendments give the Prime Minister the authority to appoint and change ministers, while this previously needed the approval of parliament and needed to take place in consultation with the country's president. The amendments established a higher threshold for the vote of no confidence in parliament, and stipulated that Mongolia's presidents' terms will from 2025 be limited to one six-year term (as opposed to the previous two four-year terms) ${ }^{34}$. Before the constitutional amendments of 2019, Mongolian laws protected judges from political pressure and the executive (in this case the president) did not have the authority to fire judges. The parliament appointed the head of the Independent Authority Against Corruption (IAAC), and the president appointed the prosecutor general ${ }^{35}$. The president and the Prime Minister's new powers, analysts continue to warn, are of great concern as Battulga had in 2014 been under investigation for the embezzlement of public funds. At the time he was forced to resign as Minister of Industry and Agriculture after accusations of having embezzled funds from a large industrial project he was overseeing. One can therefore be excused for suspecting that the president's authority to fire the head of Mongolia's anti-corruption agency might come in handy to protect himself from further corruption charges. At the time, he was investigated by the agency which since March 2019 he de facto controls.

\section{Pressure from China}

According to the scholar Mendee Jargalsaikhan, Mongolia's politics and society at large in early 2020 refrained from joining other countries (above all the US) from pointing the finger at China, blaming it for the global pandemic ${ }^{36}$. And that, as he points out, despite very deepseated anti-China sentiments among the Mongolian public. In fact,

${ }^{34}$ See J. Dierkes, Constitutional Amendments Adopted, in "Mongolia Focus", November $15,2019$.

35 B. Sambua, A. Menard, Here's how Democracy is Eroding in Mongolia, in "Washington Post", April 3, 2019.

${ }^{36}$ M. JaRgalsaikhan, Mongolia's Diplomacy Amidst the Pandemic and Geopolitical Rivalries, in "Coronabrief Friedrich Ebert Stiftung International", July 3, 2020. 
Mongolian President Battulga at the time did the very opposite of criticizing China. He became the first foreign political leader to visit China (on February 29, 2020) in the midst of the pandemic and - in a rather bizzare gesture ${ }^{37}$ - donated 30.000 sheep to China. Beijing thanked Mongolia in kind later in 2020. What in August 2020 happened in the Inner Mongolia Autonomous Region in China, home to 6 million ethnic Mongolians, confirmed already existing fears that China might in the future unilaterally decide to re-incorporate Mongolia into Chinese territory ${ }^{38}$. Inner and Outer Mongolia belonged to the Chinese/Manchu Empire from 1644-1912 and current Chinese territorial expansionism in the South Sea China, its oppressive policies in the Chinese province of Xinjiang and its occasional threats to re-unify Mainland China with Taiwan with force when possible, is near-unambiguous evidence that Beijing is in the business of expanding its national territory. Preferably within the Qing Dynasty boundaries, degrading pretty much the rest of Asia back to being Chinese 'periphery', at least if the assertive and indeed aggressive Beijing under President Xi Jinping gets its way.

In August 2020, the Chinese government decided to replace Mongolian with Mandarin Chinese in schools in Inner Mongolia. The northern Chinese region is home to roughly 17\% ethnic Mongols using Mongolian as their mother tongue ${ }^{39}$. The Chinese Ministry of Education ordered at the time that elementary and middle scholars in that region have to use Chinese for three subjects ${ }^{40}$. The subjects are: Chinese language and literature, history and law \& politics. Arguably subjects which enable the Chinese authorities to teach the 'official' Chinese version of politics and history. Like in the Chinese province of Xinjiang, the Chinese authorities are adopting policies to sinicize the culture and society and obliging minorities to speak Chinese is part of the campaign to suppress the culture, traditions and languages of Chinese minorities. The scholar Christopher Atwood argues in an interview with the Financial Times that under a new

${ }^{37}$ Bizarre at least from a Western perspective.

${ }^{38}$ Inner Mongolia was founded by the Chinese Communist party in 1947. Ethnic Mongols make up roughly 17 per cent of the 20 million people living in the region.

${ }^{39}$ See Mongolia: 'Mongolian Mother-Tongue Classes Curtailed, in "Human Rights Watch", September 4, 2020.

40 The subjects are: Chinese language and literature, history and law \& politics. Arguably subjects, which enable the Chinese authorities to teach the 'official' Chinese version of politics and history. 
so-called 'bilingual education' model Mandarin Chinese is the primary language while Mongolian is now taught as a topic and as opposed to the medium of instruction ${ }^{41}$. What can be referred to as Chinese campaign to create a Han-Chinese dominated society also in Inner Mongolia ${ }^{42}$, at the time led to school boycotts and protests throughout the autonomous region, which in turn led to arrests and detentions of activists and protest$\mathrm{ers}^{43}$. Already earlier in August 2020 the Chinese authorities shut the only Mongolian language social media platform in China. And there is very little Mongolia and Mongolians can do about Beijing's policy to erase Mongolian language and cultural heritage in Inner Mongolia ${ }^{44}$. While some Mongolian politicians and civil society protested on social media, Mongolia is in reality reduced to being a bystander watching the gradual Sinicization of Inner Mongolia from a distance ${ }^{45}$.

\section{Depending on China}

Mongolia will continue to remain heavily dependent on mineral exports to China. In 2020 China accounted for almost $90 \%$ of Mongolia's exports (and roughly 35\% of its imports). That in turn means that maintaining good and problem-free relations with China is imperative for Mongolia. Not least as China has in the past not shied away from imposing economic sanctions and retaliatory policies onto countries, which dared to 'interfere' in Chinese domestic and foreign policies. 'Interfere' as in of having and expressing a critical opinion on any aspect or area of Chinese domestic and foreign policies ${ }^{46}$. The Philippines, Mongolia and

${ }^{41}$ See also C. SHEPHERD, China's Clampdown on Use of Mongolian in Schools Sparks Protests, in "The Financial Times", September 1, 2020.

${ }^{42}$ Like in Xinjiang and Tibet.

${ }^{43}$ H. DAVIDSON, Inner Mongolia Protests at China's Plans to Bring in Mandarin-only Lessons only, in "The Guardian", September 1, 2020.

${ }^{44}$ When the Mongolian government received the Dalai Lama in 2016, Beijing partially interrupted and imposed high tariffs onto Mongolian exports until the government promised to never again allow Tibet's spiritual leader to visit Mongolia.

45 A. GRACEFFCO, China's Crackdown on Mongolian Culture, in "The Diplomat", September 4, 2020.

46 All of which is in Beijing categorically and almost automatically referred to as "interference" and treated (i.e. punished) as such. 
currently Australia have all been targeted by Chinese economic retaliation in recent years and Mongolia's near-complete economic dependence on China makes the country particularly vulnerable to Chinese political pressure ${ }^{47}$. China also provides electricity to Mongolia's key mining project, Oyu Tolgoi. Electricity at an annual rate of between us\$ 100 and 130 billion ${ }^{48}$. In 2019, the government announced that the indigenous power plant will become operational by $2023^{49}$. That was on the basis of a previous agreement between the government and Rio Tinto, but that deadline was further postponed - by at least two years until 2025. All of this means that the Oyu Tolgoi mine will continue to pay for electricity to Chinese providers for another four-five years.

Mongolia's total coal exports during 2020 fell by $22 \%$ to 28.6 million tonnes, 12 million tonnes below the target set by the government at the beginning of 2020. Before the global pandemic broke out in early 2020 , the government announced that coal exports in 2020 would exceed 40 million tonnes ${ }^{50}$. When Mongolian coal deliveries to China resumed on March 23, the number of trucks crossing the Mongolian-Chinese border were limited to several hundred trucks per day. Normally, more than 1.000 Mongolian trucks make that trip every day. When a new wave of the Covid-19 pandemic hit again parts of China and Mongolia in November 2020, coal deliveries were again temporarily interrupted. Luckily for Mongolia the Chinese decision to sharply restrict Australian coking coal imports - as part of Chinese economic retaliation for Canberra daring to express its (strong) concerns over the treatment of Uighur Muslims in Chinese detention camps in the Chinese province of Xinjiang - Chinese demand for Mongolian coking coal increased in 202051. Coal traders

47 J. Anderlini, China is Escalating its Punishment Diplomacy, in "The Financial Times", September 23, 2020.

${ }^{48}$ See e.g. Tavan Tolgoi Power Station (Rio Tinto), in "Global Energy Monitor Wiki", October 28, 2020.

${ }^{49}$ N. Hume, Mongolia Says Rio-led Copper Projects will go Ahead, in "The Financial Times", November 26, 2019.

${ }^{50}$ S. XIE, Mongolia 2020 Coal Exports Shrink by 22\% to 29 t', in “The Coal Hub", January 14, 2021.

${ }^{51}$ For Australia - together with 40 other countries - expressing concerns about Beijing's ongoing violation of human rights Xinjiang see D. HuRst, Australia Joins Global Condemnation of China over Xinjiang Amid Deteriorating Ties, in "The Guardian", October 7, 2020. 
in North and Northwest China were ordered to replace Australian with Mongolian coal and given the geographical vicinity, had few problems doing that. Mongolia's crude oil exports to China too took a hit in 2020. The country produces a relatively a small amount of crude oil (6 to 8 million barrels per year) and exports this oil to China. The exports of crude oil have already slumped significantly in the first 4-5 months of 2020 and the end of August of the same year, Mongolia exported only roughly 1.8 million barrels to China, roughly $50 \%$ less than during the same period of 2019.

\section{Russia-Sometimes (False) Friend, Often Foe}

In 2019 Russia and Mongolia signed the bilateral Permanent Treaty of Friendship and Moscow set up a US\$ 1.5 billion investment fund to finance infrastructure projects in Mongolia. Recently, the Russian government wrote off $98 \%$ percent of Mongolia's state debt and bilateral trade increased by $40 \%$ in recent years ${ }^{52}$. Almost all of Mongolia's oil imports come from Russia (more than 80\%). Mongolian dependence on Russian oil is here to stay, and in 2018 the Russian state-owned oil company Rosneft signed us $\$ 2.1$ billion worth of contracts with Mongolian oil importers. Today, the scholar Erin Parsons writes that Russia's geopolitical regional interests in Mongolia are the same as the former Soviet Union's: above all protecting its southern border with China. This, Parsons conclude, has led to Russia, China, and the United States treating Mongolia no longer merely as what she calls 'bargaining chip' but instead as an actual regional actor. Russian experts interviewed by the newspaper Nikkei Asian Review point out

\footnotetext{
Australia has joined the US and the UK in announcing to want to closely monitor companies using supply chains and suppliers in Xinjiang. Local companies in Xinjiang are among other accused of using forced labour for their supply chains (in essence, Uighur prisoners detained in the above-mentioned 're-education camps'). For details see e.g. D. StrInger, Australia Joins U.S., U.K. in Warning Firms over Xinjiang Ties, Bloomberg, January 16, 2021.

52 See N. Mikovic, Russian Influence in Mongolia is Declining, in "Global Security Review", June 9, 2019; for further details see also V. KRISHNA, Mongolia's Foreign Policy: Profiling Fundamental Aspects in "International Journal of Applied Social Science", September/October 2017, pp. 402-414.
} 
that there are concerns in Moscow about Beijing's growing economic influence in and over Mongolia. In fact, balancing Chinese influence in Mongolia has become a priority in Moscow, the Japanese newspaper cited Alexei Maslov, professor at the National Research University Higher School of Economics in Moscow. Maslov is not alone in Russia fearing that Beijing could one day decide to swallow Mongolia ${ }^{53}$. In that case, Maslov warns, Russian security interests will be at stake as $70 \%$ of Russia's border will be with China ${ }^{54}$. The Russian scholar Sergey Radchenko argues in the same Nikkei article that Moscow's decision in the early 1990 to discharge Mongolia as an economic burden with little strategic value has come back to haunt Russia today. Hence, Moscow's recent efforts to engage Mongolia economically and assign greater importance to bilateral political and security ties, Radchenko maintains ${ }^{55}$. Indeed, Moscow seems to have rediscovered Mongolia's strategic importance because of Chinese economic dominance everywhere in Central Asia, traditionally Russia's geo-strategic backyard. In March 2020, Russian President Vladimir Putin and Gazprom executives got together to proceed to the pre-investment phase in the Power of Siberia 2 project, a gas pipeline project involving China and Mongolia ${ }^{56}$. Mongolia's participation in the 2.000 kilometres long gas pipeline which will run through Mongolia (also through the capital Ulaanbatar) was sealed in June 2019 through a Russian-Mongolian Memorandum of Understanding (MOU) ${ }^{57}$. Mongolia's participation in the Power of Siberia 2 project will make Mongolia a transit country in the Russia-China supply chain of gas in Northeast Asia. Russia supplies $92 \%$ of Mongolia's demand in gas.

Moscow, of course, is not all carrots but also sticks, as it turned out in 2020 when it made it clear that it has yet to come to terms with Mon-

53 After World War II Soviet dictator Joseph Stalin pushed China to recognize an independent Mongolia. In exchange for abandoning support of the Uighur independence movement in Xinjiang, Beijing officially recognized Mongolia in January 1946.

${ }^{54}$ See Russia Renews Interest in Mongolia to Counter Chinese Influence, in "Nikkei Asia", October 3, 2019.

55 Director of research at Cardiff University School of Law \& Politics.

${ }^{56}$ B. LKhaAjaV, Mongolia Securing an Energy Alliance with Russia and China, in "The Diplomat", July 2, 2020.

${ }^{57}$ See Gas Pipeline to run through Mongolia,in "Montsame Mongolian News Agency", June 12, 2019. 
golian independence and foreign policy autonomy 58 . When Russia on June 24 held a military parade to commemorate the 75th anniversary of Victory in Europe Day, Mongolian National Broadcaster (MNB) decided not to broadcast the Russian military parade. The broadcast was cancelled because Mongolian general elections were held on the same day, Sergey Radchenko writes in Foreign Policy. While the MNB did not want to be accused of bias on election day, Moscow took the cancellation very personally and its embassy in Ulaanbaatar was ordered to smell conspiracy. Over Facebook the Russian embassy accused MNB (and indirectly the government) of 'subservience' to Western interests and of joining the campaign of accusing Russia of electoral interference all over the world 59 .

\section{Trilateralism, maybe}

In 2020 Mongolian president Battulga further raised the prospects of Mongolia joining the Shanghai Cooperation Organization (SCO), a regional security organization dominated by Beijing and Moscow ${ }^{60}$. For years, both Russia and China have been urging Mongolia to join the SCO in an effort to pull the country away from developing closer political and military relations with the West in general, and the Us in particular. Mongolia has until recently been reluctant to join the SCO as that would put Mongolia's so-called Third Neighbour Policy in jeopardy ${ }^{61}$. What is meant with Mongolia's Third Neighbour policy are the country's efforts and policies to intensify political and security relations with democratic countries like the US, Japan, South Korea, India and the European Union (EU). An alternative to asymmetric relations with Mongolia's authoritar-

${ }^{58}$ Following the 1990 Democratic Revolution in Mongolia. Mongolia became an independent country in 1921 but was until the collapse of the Soviet Union in 1991 treated as quasi-Soviet republic.

${ }^{59}$ S. Radchenko, Russia Wants to Keep Mongolia in its Place, in "Foreign Policy", June 28, 2020.

${ }^{60}$ Founded in 2001.

${ }^{61}$ For details of Mongolia Third Neighbour Policy see e.g. S. SonI, The Third Neighbour Approach of Mongolia's Diplomacy of External Relations: Effects on Relations between India and Mongolia, in "India Quarterly. A Journal of International Affairs", n. 1, March 2015, pp. 37-52. 
ian "first" and "second" neighbours Russia and China62. In July 2020, Moscow put its SCO invitation on the record although it emphasised at the time that it has "no intention to influence the choice of our Mongolian friends" 63 . One can believe that or not, but given how Moscow reacted to Mongolian television not covering Moscow's World War II victory celebrations, it is probably hard to believe the latter. Moscow at the time made it very clear that indeed it had and will continue to have the intention to meddle and interfere in Mongolian domestic politics. The reason why, Alicia Campi explains, Mongolia has opted for Trilateralism as a complementary element of the country's Third Neighbour Policy64. The idea of two legs of trilateral ties dates back to 2014 and Sino-Russia rapprochement after the West imposed economic sanctions onto Russia ${ }^{65}$. At the time, Campi points out, former Mongolian President Tsakhia Elbegdorj was worried that China's Euroasian Silk Road (today: the Belt and Road Initiative, BRI) would not include Mongolia and proposed for the country to pursue the aforementioned trilateralism. Reviving Russian investments in Mongolia and increasing Russian contributions to upgrade Mongolian domestic railway transport infrastructure became a priority for the Mongolian government at the time. A northward rail link to link with the Trans-Siberian rail system and southward rail link to improve railway connections with China. While Trilateralism Mongolian-style stands for foreign pragmatism, on the ground it might be difficult to practice. The more Mongolia's dependence on Russia and more importantly China increases, the more difficult it will become for the country to exercise foreign and foreign economic policy Trilateralism.

\section{Conclusions}

While there are increasing investments by the Us, Japan, South Korea and the EU in Mongolia, such investments will continue to re-

\footnotetext{
62 The term Third Neighbour was first used in 1990 by then US Secretary of State James A. Baker. Washington, he declared at the time, is Mongolia's Third Neighbour.

${ }^{63}$ See Russia to Support Mongolia if it Opts to Become Full Member of SCO-Diplomat, in "Tass, Russian News Agency", July 2, 2020.

${ }^{64}$ A. CAMPI, Mongolia's Response to Increasing U.S.-China-Russia Rivalry in Asia, in “Asia-Pacific Bulletin", n. 521, East-West Center, August 7, 2020.

65 After Russia's unlawful annexation of Crimea.
} 
main very small as compared to what China and Russia have to offer in terms of export destination for Mongolian coal, oil and other commodities. But there is no free lunch for Mongolia with Moscow and Beijing either as Russia and Chinese interference in Mongolian and foreign policies in recent years demonstrate. Analysts often point out that Mongolia has over years played successfully China against Russia and vice versa obtaining maximum benefits as Moscow and Beijing were competing to win Mongolia's favour. However, that strategy - if it really ever was one - is no longer sustainable since Russia and China have moved beyond a fair-weather friendship towards an alliance, finding themselves - at least so it seems - in near-perfect alignment against the West (when it suits their interests). For what it is worth, in 2019 the Us became Mongolia's 5th "strategic partner" to counter Russian and Chinese influence. Among others, the bilateral partnership foresees increased us investments in Mongolia, technical and financial support for Mongolian small and medium enterprises (SMEs) ${ }^{66}$. However, by the end of 2020 Washington had yet to put the money where its mouth is. Indeed, under President Joe Biden Washington has some catchingup to do as the amount of Us financial support for Mongolia decreased from us\$ 46 million in 2018 to just US\$ 12 million in 202067.

Mongolia's democracy is fragile because of a corrupt political class and political parties which buy themselves votes for political and material favours. Furthermore, Mongolian politics' increasing authoritarian tendencies put the often pronounced country's status as a "democratic oasis" in an authoritarian neighbourhood in doubt. While the aforementioned Mongolian Trilateralism is a sensible foreign policy approach, it will most probably continue to be an also-ran of onthe-ground Mongolian foreign policies. Also because Mongolian foreign policy is in the process of prioritizing geographical contiguity and economic pragmatism over Third Neighbour Policy with far away fellow democracies as the scholar Vladimir Rodionov argues ${ }^{68}$. Mon-

${ }^{66}$ B. LkhaAJav, US Becomes Mongolia's 5th Strategic Partner, in "The Diplomat" August 5, 2019.

67 B. LKHAAJAV, How Changing US Administrations Shape Mongolia-US Relations, in "The Diplomat" December 3, 2020.

68 V. Rodionov, Foreign Policy of Kh. Battulga (2017-2020), in "Mongolian Journal of International Affairs" December 21, 2020; p.91-100. 
golian President Battulga in 2020 questioning the country's principle of Permanent Neutrality and his caving in to pressure to join the SCO as a full member is evidence of that, Rodionov concludes. Finally, there are concerns that Mongolia might find itself in the middle of geopolitical and geo-economic competition between China and the United States. Both have claimed Mongolia as important for their competing foreign and foreign economic policies in the Indo-Pacific Region: China's Belt and Road Initiative and the us 'Free and Open Indo-Pacific'69. Then again Mongolia is as an actor probably not important enough to get Beijing and Moscow to compete with Washington over influence in Mongolia beyond the current level.

\begin{abstract}
Riassunto - La quasi completa dipendenza economica della Mongolia da Cina e Russia è destinata a durare, accentuata dalla pandemia in atto. Il governo mongolo ha adottato un massiccio pacchetto di stimoli economici e fiscali per contrastare le ripercussioni della pandemia sull'economia del paese. Ma questi non sono tempi favorevoli nemmeno per la democrazia mongola. Le elezioni di giugno 2020, infatti, hanno avviato il paese verso quello che viene definito "sviamento democratico": cioè un percorso che parte da una democrazia liberale e si avvia verso quella che, nel caso della Mongolia, sta diventando una democrazia quasi unipartitica gravata da corruzione, nepotismo e dalla violazione del principio di separazione dei poteri. Sebbene la Cina non metta ancora in di-
\end{abstract}

scussione l'indipendenza della Mongolia, si teme che più la Cina diventa forte ed economicamente potente, più potrebbe essere tentata, in un futuro non lontano, di includere anche la Mongolia Esterna nel territorio cinese. La decisione di Pechino, a metà del 2020, di sradicare ulteriormente la lingua, la cultura e il patrimonio culturale mongolo nella regione autonoma della Mongolia interna ha suscitato allarme nella capitale della Mongolia, Ulan Bator. Il presidente mongolo Battulga Khaltmaa, nel frattempo, sembra ansioso di schierarsi dalla parte della Russia e della Cina e progetta di cedere alla sollecitazione di Mosca di sostituire lo status di osservatore della Mongolia con la piena adesione all'Organizzazione per la Cooperazione di Shanghai (SCO).

${ }^{69}$ M. Siow, US-China Tensions: Why Mongolia is in the Middle of a New Cold War, in "South China Morning Post" August 15, 2020. 